NBER WORKING PAPER SERIES

\title{
THE UNHOLY TRINITY OF FINANCIAL CONTAGION
}

\author{
Graciela L. Kaminsky \\ Carmen M. Reinhart \\ Carlos A. Vegh \\ Working Paper 10061 \\ http://www.nber.org/papers/w10061
}

\author{
NATIONAL BUREAU OF ECONOMIC RESEARCH \\ 1050 Massachusetts Avenue \\ Cambridge, MA 02138 \\ October 2003
}

The authors wish to thank Laura Kodres, Vincent Reinhart, and Miguel Savastano for very useful comments and suggestions and Kenichi Kashiwase for excellent research assistance

The views expressed herein are those of the authors and not necessarily those of the National Bureau of Economic Research.

(C2003 by Graciela L. Kaminsky, Carmen M. Reinhart, and Carlos A. Vegh. All rights reserved. Short sections of text, not to exceed two paragraphs, may be quoted without explicit permission provided that full credit, including $(\mathrm{C}$ notice, is given to the source. 
The Unholy Trinity of Financial Contagion

Graciela L. Kaminsky, Carmen M. Reinhart, and Carlos A. Vegh

NBER Working Paper No. 10061

October 2003

JEL No. F30, F31, F32

\title{
ABSTRACT
}

Over the last 20 years, some financial events, such as devaluations or defaults, have triggered an immediate adverse chain reaction in other countries -- which we call fast and furious contagion. Yet, on other occasions, similar events have failed to trigger any immediate international reaction. We argue that fast and furious contagion episodes are characterized by "the unholy trinity": (i) they follow a large surge in capital flows; (ii) they come as a surprise; and (iii) they involve a leveraged common creditor. In contrast, when similar events have elicited little international reaction, they were widely anticipated and took place at a time when capital flows had already subsided.

\author{
Graciela L. Kaminsky \\ Department of Economics \\ George Washington University \\ Washington, DC 20052 \\ and NBER \\ graciela@gwu.edu \\ Carmen Reinhart \\ University of Maryland \\ School of Public Affairs and Department of Economics \\ 4105 Van Munching Hall \\ College Park, Maryland 20742 \\ and NBER \\ creinhar@umd.edu \\ Carlos A. Vegh \\ Department of Economics \\ University of California, Los Angeles \\ Los Angeles, CA 90095-1477 \\ and NBER \\ cvegh@ucla.edu
}


For reasons that are not always evident at the time, some financial events, such as the devaluation of a currency or an announcement of default on sovereign debt obligations, trigger an immediate and startling adverse chain reaction among countries within a region and in some cases across regions. This phenomenon, which we dub "fast and furious" contagion, was manifest after the floatation of the Thai baht on July 2, 1997, as it quickly triggered financial turmoil across East Asia. Indonesia, Korea, Malaysia, and the Philippines were hit the hardest — by December 1997, their currencies had depreciated (on average) by about 75 percent. Similarly, when Russia defaulted on its sovereign bonds on August 18, 1998, the effects were felt not only in several of the former Soviet republics, but also in Hong Kong, Brazil, Mexico, many other emerging markets, and the riskier segments of developed markets. ${ }^{1}$ The economic impact of these shocks on the countries unfortunate enough to be affected included declines in equity prices, spikes in the cost of borrowing, scarcity in the availability of international capital, and declines in the value of their currencies and in output.

Table 1 presents summary material for recent contagion episodes. The first column lists the country, the date that marks the beginning of the episode, the nature of the shock, and currency market developments in the crisis country, while the remaining columns include information on the existence and nature of common external shocks, the suspected main mechanism for propagation across national borders, and the countries that were most affected.

The challenge for economic researchers is to explain why the number of financial crises that did not have significant international consequences is far greater than those that did. It is no surprise that a domestic crisis (no matter how deep) in countries that are 
approximately autarkic (either voluntarily or otherwise) will not likely have immediate repercussions in world capital markets. The countries may be large (China or India) or comparatively small (Bolivia and Guinea-Bissau.) More intriguing cases of "contagion that never happened" are where the crisis country is relatively large (at least by emerging market standards) and is reasonably well integrated to the rest of the world through trade or finance. Along with the fast and furious contagion episodes, these are the cases we focus on in this paper.

Some recent examples of financial crises with limited immediate consequences include Brazil's devaluation of the real on January 13, 1999 and eventual flotation on February 1, the Argentine default and abandonment of the Convertibility Plan in December 2001, and Turkey's devaluation of the lira on February 22, 2001. Given that Brazil, Turkey, and Argentina are relatively large emerging markets, these episodes could have been-at least potentially--as highly "contagious" as the Thai and Russian crises. Nonetheless, financial markets shrugged off these events, despite the fact that it was evident at the time that some of these shocks would have trade and real sector repercussions on neighboring countries over the medium term. ${ }^{2}$ Table 2 presents some summary material for these episodes, in a format parallel to Table 1.

This paper seeks to address the central question of why financial contagion across borders occurs in some cases but not others. ${ }^{3}$ Throughout the paper, we stress that there are three key elements - an abrupt reversal in capital inflows, surprise announcements, and a leveraged common creditor (the unholy trinity)--that distinguish the cases where contagion occurs from those where it does not. 
First, contagion usually followed on the heels of a surge in inflows of international capital and, more often than not, the initial shock or announcement pricked the capital flow bubble, at least temporarily. The capacity for a swift and drastic reversal of capital flows - the so-called "sudden stop" problem—played a significant role. ${ }^{4}$

Second, the announcements that set off the chain reactions came as a surprise to financial markets. The distinction between anticipated and unanticipated events appears critical, as forewarning allows investors to adjust their portfolios in anticipation of the event.

Third, in all cases where there were significant immediate international repercussions, a leveraged common creditor was involved — be it commercial banks, hedge funds, mutual funds, or individual bondholders - who helped to propagate the contagion across national borders.

Before turning to the question of what elements distinguish the cases where contagion occurs from those where it does not, however, we provide a brief tour of the main theoretical explanations for contagion and the most salient empirical findings on the channels of propagation.

\section{What is Contagion?}

Since the term "contagion" has been used liberally and taken on multiple meanings, it is useful to clarify how it will be used in this paper. We refer to contagion as an episode in which there are significant immediate effects in a number of countries following an event--that is, when the consequences are fast and furious and evolve over a matter of hours or days. This "fast and furious" reaction is a contrast to cases in which 
the initial international reaction to the news is muted. The latter cases do not preclude the emergence of gradual and protracted effects that may cumulatively have major economic consequences. We refer to these gradual death by a thousand cuts cases as spillovers. Common external shocks, such as changes in international interest rates or oil prices, are also not automatically included in our working definition of contagion. Only if there is "excess comovement" in financial and economic variables across countries in response to a common shock do we consider it contagion.

\section{Theories of Contagion}

Through what channels does a financial crisis in one country spread across international borders? Some models have emphasized investor behavior that gives rise to the possibility of herding and fads. It is no doubt possible (if not appealing to many economists) that such "irrational exuberance," to quote Federal Reserve Chairman Alan Greenspan, influence the behavior of capital flows and financial markets and exacerbates the booms as well as the busts. Other models stress economic linkages through trade or finance. This section provides a selective discussion of theories of contagion. The main message conveyed here - consistent with our unholy trinity proposition--is that financial linkages (i.e., cross border capital flows and common creditors) and investor behavior figure the most prominently in the theoretical explanations of contagion.

\section{Herding}

Bikhchandani, Hirshleifer, and Welch (1992) model the fragility of mass behavior as a consequence of informational cascades. ${ }^{5}$ An information cascade occurs when it is 
optimal for an individual, after observing the actions of those ahead of him, to follow the behavior of the preceding individual without regard to his or her own information. Under relatively mild conditions, cascades will almost surely start, and often they will be wrong. In those circumstances, a few early individuals can have a disproportionate effect.

Changes in the underlying value of alternative decisions can lead to "fads," that is drastic and seemingly whimsical swings in mass behavior without obvious external stimulus.

Banerjee (1992) also develops a model to examine the implications of decisions that are influenced by what others are doing. The decisions of others may reflect potentially important information in their possession that is not in the public domain. With sequential decision making, people paying attention to what others are doing before them end up doing what everyone else is doing (i.e., herding behavior), even when one's own private information suggests doing something different. The herd externality is of the positive feedback type: If we join the crowd, we induce others to do the same. The signals perceived by the first few decision makers-random and not necessarily correct-determine where the first crowd forms, and from then on, everybody joins the crowd. This characteristic of the model captures (to some extent) the phenomena of "excess volatility" in asset markets, or the frequent and unpredictable changes in fashions.

Another story suggests that the channels of transmission arise from the global diversification of financial portfolios in the presence of information asymmetries. Calvo and Mendoza (1998), for instance, present a model where the fixed costs of gathering and processing country-specific information give rise to herding behavior, even when investors are rational. Because of information costs, there are equilibria in which the marginal cost exceeds the marginal gain of gathering information. In such instances, it is 
rational for investors to mimic market portfolios. When a rumor favors a different portfolio, all investors "follow the herd."

\section{Trade Linkages}

Some recent models have revived Nurkse's (1944) classic story of competitive devaluations (Gerlach and Smetts, 1996). Nurkse argued that since a devaluation in a one country makes its goods cheaper internationally, it will pressure other countries that have lost competitiveness to devalue as well. In this setting, a devaluation in a second country is a policy decision whose effect on output is expected to be salutary, as it induces expenditure-switching (i.e. reduces imports, increases exports, and improves the current

account.) An empirical implication of this type of model is that we should observe a high volume of trade among the "synchronized" devaluers. As a story of voluntary contagion, this explanation does not square with the fact that central banks often go to great lengths to avoid a devaluation in the first place (often by engaging in an active interest rate defense of the existing exchange rate, as in Lahiri and Végh, 2003) or by enduring massive losses of foreign exchange reserves nor that devaluations have often been contractionary.

\section{Financial Linkages}

Other studies have emphasized the important role of common creditors and financial linkages. The "type" of the common creditor may differ across models but the story tends to remain consistent. 
In Shleifer and Vishny (1997), arbitrage is conducted by relatively few specialized and leveraged investors, who combine their knowledge with resources that come from outside investors to take large positions. Funds under management become responsive to past performance. The authors call this Performance Based Arbitrage (PBA). In extreme circumstances, when prices are significantly out of line and arbitrageurs are fully invested, PBA is particularly ineffective. In these instances, arbitrageurs might bail out of the market when their participation is most needed. That is, arbitrageurs face fund withdrawals, and are not very effective in betting against the mispricing. Risk averse arbitrageurs might chose to liquidate, even when they do not have to, for fear that a possible further adverse price movement may cause a drastic outflow of funds later on. While the model is not explicitly focused on contagion, one could see how an adverse shock that lowers returns (say, like the Mexican peso crisis) may lead arbitrageurs to liquidate their positions in other countries that are part of their portfolio (Argentina, Brazil, etc.), as they fear future withdrawals.

Similarly, Calvo (1998) has stressed the role of liquidity. A leveraged investor facing margin calls needs to sell asset holdings. Because of the information asymmetries, a "lemons problem" arises and the asset can only be sold at a firesale price. For this reason, the strategy will be not to sell the asset whose price has already collapsed, but other assets in the portfolio. In doing so, however, other asset prices fall and the original disturbance spreads across markets.

Kodres and Pritsker (2002) develop a rational expectations model of asset prices to explain financial market contagion. In their model, assets' long run values are determined by macroeconomic risk factors, which are shared across countries, and by 
country-specific factors. Contagion occurs when "informed" investors respond to private information on a country-specific factor, by optimally rebalancing their portfolio's exposures to the shared macroeconomic risk factors in other countries' markets. When there is asymmetric information in the countries hit by the rebalancing, "uninformed" investors cannot fully identify the source of the change in asset demand; they therefore respond as if the rebalancing is related to information on their own country (even though it is not). As a result, an idiosyncratic shock generates excess co-movementcontagion — across countries' asset markets. A key insight from the model is that contagion can occur between two countries even when contagion via correlated information shocks, correlated liquidity shocks, and via wealth effects are ruled out by assumption, and even when the countries do not share common macroeconomic factors, provided that both share at least one underlying macroeconomic risk factor with a third country, through which portfolio rebalancing can take place. Their model, like the rational herding model of Calvo and Mendoza (1998), has the empirical implication that countries with more internationally-traded financial assets and more liquid markets should be more vulnerable to contagion. Small, highly illiquid markets are likely to be under-represented in international portfolios to begin with and, as such, shielded from this type of contagion.

Kaminsky and Reinhart (2000) focus on is the role of commercial banks in spreading the initial shock. The behavior of foreign banks can exacerbate the original crisis by calling loans and drying up credit lines, but can also propagate crises by calling loans elsewhere. The need to rebalance the overall risk of the bank's asset portfolio and 
to recapitalize following the initial losses can lead to a marked reversal in commercial bank credit across markets where the bank has exposure.

\section{Other Explanations}

The so-called "wake-up call hypothesis" (a term coined by Morris Goldstein, 1998) relies on either investor irrationality or a fixed cost in acquiring information about emerging markets. In this story, once investors "wake up" to the weaknesses that were revealed in the crisis country, they will proceed to avoid and move out of countries that share some characteristics with the crisis country. So, for instance, if the original crisis country had a large current account deficit and a relatively "rigid" exchange rate, then other countries showing similar features will be vulnerable to similar pressures (see Basu, 1998, for a formal model).

\section{Channels of Propagation: The Empirical Evidence}

As discussed, some theoretical models emphasized trade linkages as a channel for the cross-border propagation of shocks, while most models have looked to financial markets for an explanation.

Perhaps because trade in goods and services has a longer history in the post World War II period than trade in financial assets, or because of far better data availability, trade links have received the most attention in the empirical literature on channels of contagion. Eichengreen, Rose, and Wyplosz (1996) find evidence that trade links help explain the pattern of contagion in 20 industrial countries over 1959-1993. Glick and Rose (1999), who examine this issue for a sample of 161 countries, come to the same 
conclusion. Glick and Rose (1999) and Kaminsky and Reinhart (2000) also study trade linkages which involve competition in a common third market. While sharing a third party is a necessary condition for the competitive devaluation story, Kaminsky and Reinhart (2000) argue it is clearly not a sufficient one. If a country that exports wool to the United States devalues, it is not obvious why this would have any detrimental effect on a country that exports semiconductors to the United States. Their study shows that third-party trade links is a plausible transmission channel in some cases but not for the majority of countries recently battered by contagion. For example, at the time of the Asian crisis, Thailand exported many of the same goods to the same third parties as Malaysia. This, however, does not explain all the other Asian crisis countries. Bilateral or third party trade also does not appear to carry any weight in explaining the effects of Mexico (1994) on Argentina and Brazil. At the time of Mexico's 1994 devaluation, only about 2 percent of Argentina's and Brazil's total exports went to Mexico. Similarly, Brazil hardly trades with Russia, as only 0.2 percent of its exports are destined for Russian markets; yet in the weeks following the Russian default Brazil's interest rate spreads doubled and Brazil's equity prices fell by more than 20 percent.

Kaminsky and Reinhart (2000) compare countries clustered along the lines of trade links versus countries with common bank creditors, and conclude that common financial linkages better explains the observed pattern of contagion. Mody and Taylor (2002), who seek to explain the comovement in an exchange market pressures index by bilateral and third-party trade and other factors, also cast doubt on the importance of trade linkages in explaining the propagation of shocks. 
Conversely, in many cases of crises without contagion, there are strong trade links. About 30 percent of Argentina's exports are destined for Brazil, yet in the week following Brazil's devaluation, the Argentine equity market increases 12 percent. Similarly, nearly 13 percent of Uruguay's exports are bound for the Argentine market. Yet, the main reason why the crisis in Argentina ultimately affected Uruguay was the tight financial linkages between the two countries. Uruguayan banks have (for many years) been host to Argentinean depositors, who thought their deposits safer when these were denominated in U.S. dollars and kept across the Río de la Plata. At first, as the crisis deepened in Argentina, many deposits fled from Argentine banks and found their way to Uruguay. But when the Argentine authorities declared a freeze on bank deposits in December 2001, Argentine firms and households began to draw down the deposits they kept at Uruguayan banks. The withdrawals escalated and became a run on deposits amid fears that the Uruguayan central bank would either run out of international reserves or (like Argentina) confiscate the deposits.

Other studies focused primarily on financial channels of transmission. Frankel and Schmukler (1998) and Kaminsky, Lyons, and Schmukler (2000) show evidence to support the idea that US-based mutual funds have played an important role in spreading shocks throughout Latin America by selling assets from one country when prices fall in another - with Mexico's 1994 crisis the being a prime example. Caramazza, Ricci, and Salgado (1999), Kaminsky and Reinhart (2000), and Van Rijckeghem and Weder (2000) focus on the role played by commercial banks in spreading shocks and inducing a sudden stop in capital flows in the form of bank lending, especially in the debt crisis of 1982 and the crisis in Asia in 1997. Mody and Taylor (2002) link contagion to developments in the 
US high yield or "junk" bond market. The common thread in these papers is that, without the financial sector linkages, contagion of the fast and furious variety would be unlikely.

\section{Summing Up}

Table 3 summarizes the some of the arguments about propagation of contagion among the five fast and furious cases emphasized earlier: Mexico in 1982, the European Exchange Rate Mechanism crises of 1992, Mexico's currency devaluation in 1994, Thailand's devaluation in 1997, and Russia's devaluation in $1998 .{ }^{6}$ In each case, we consider the possible trade channel, whether the affected countries shared similar characteristics with the crisis country and with each other, and whether a common creditor was present with the possible financial channel. Indeed, Table 3 lays the foundation for our unholy trinity of financial contagion proposition, which the next section discusses in greater detail. Several features summarized in Table 3 are worth highlighting. In all five cases, a common leveraged creditor was present, making it consistent with the explanations offered by Schleifer and Vishny (1997), Calvo (1998), and discussed in Kaminsky and Reinhart (2000). In three of the five cases, the scope for propagation via trade links is virtually nonexistent and in one of the two remaining cases (Thailand) the extent of third party competition is with Malaysia, not the other affected Asian countries. Lastly, with the exception of the countries that suffered most from Russia/LTCM fallout, the affected countries tended to have large capital inflows and relatively fixed exchange rates. 


\section{The Unholy Trinity: Capital Inflows, Surprises, and Common Creditors}

Having summarized some of the key findings of the literature on contagion, we now return to our central question of why contagion occurs in some instances but not in others.

\section{The Capital Flow Cycle}

Fast and furious contagion episodes are typically preceded by a surge in capital inflows which, more often than not, come to an abrupt halt or sudden stop in the wake of a crisis. The inflow of capital may come from banks, other financial institutions, or bondholders. The debt contracts typically have short maturities, which means that the investors and financial institutions will have to make decisions about rolling over their debts - or not doing so. With fast and furious contagion, investors and financial institutions are exposed to the crisis country and often highly leveraged. Thus, the investors can be viewed as halfway through the door, ready to back out on short notice.

This rising financial exposure to emerging markets is not present to nearly the same extent in the crises without major external consequences. Financial crises that have not set off major international dominos have usually unfolded against low volumes of international capital flows. Given lower levels of exposure, investors and institutions in the financial sector have a much lower need to adjust their portfolios when the shock occurs. In many instances, because the shock is anticipated, portfolios were adjusted prior to the event.

In all five of the examples from Table 1, the capital flow cycle has also played a key role in determining whether the effects of a crisis have significant international ramifications. For example, in the late 1970s, soaring commodity prices, low and 
sometimes negative real interest rates (as late as 1978 real interest rates oscillated between minus two percent and zero), and weak loan demand in the United States made it very attractive for U.S. banks to lend to Latin America and other emerging markets—and lend they did. Capital flows, by way of bank lending, surged during this period, as shown in Figure 1. By the early 1980s, the prospects for repayment had significantly changed for the worse. U.S. short-term interest rates had risen markedly in nominal terms (the federal funds rate went from below 7 percent in mid 1978 to a peak of about 20 percent in mid-1981) and in real terms (by mid-1981 real short-term interest rates were around 10 percent, the highest level since the 1930s.) Since most of the loans made had either short maturities or variable interest rates, the effects were passed on to the borrower relatively quickly. Commodity prices had fallen almost 30 percent between 1980 and 1982, and many governments in Latin America were engaged in spending sprees that would seal their fate and render them incapable of repaying their debts. In 1981, Argentina's public sector deficit as a percent of GDP was about 13 percent while Mexico's was 14 percent; during 1979-80 Brazil's deficit was of a comparable order of magnitude. Prior to Mexico's default in August 1982, one after another of these countries had already experienced currency crises, banking crises, or both. When Mexico ultimately defaulted, the highly exposed and leveraged banks retrenched from emerging markets in general and Latin America in particular.

During the decade that followed, there were numerous crises in Latin America, including some severe hyperinflations (Bolivia in 1985, and Peru, Argentina, and Brazil in 1990) and other defaults. Yet, these crises had minimal international repercussions, as 
most of the region was shut out of international capital markets. The drought in capital flows lasted until 1990.

Figure 1 shows net private capital flows for the contagion episodes of the 1990s, while Table 4 provides complementary information on capital flows and capital flight for the crisis country and those affected by it. Again, notice the common pattern of a run-up in borrowing followed by a crash at the time of the initial shock and much inflows of capital thereafter. Net private capital flows to Europe had risen markedly and peaked in 1992 before coming to a sudden stop after the collapse of the Exchange Rate Mechanism crisis, in which the attempt to hold exchange rates within preset bands fell apart under pressure from international arbitrageurs. The crisis in the European Monetary System in 1992-93 showed that emerging markets do not have a monopoly on vulnerability to contagion, although they certainly tend to be more crisis prone.

In the case of Mexico, as the devaluation of the peso loomed close late in 1994, capital flows were close to their 1992 peak after surging considerably. (As late as 1989, Mexico had recorded net large capital outflows.) The rise in capital flows to the East Asian Indonesia, Korea, Malaysia, the Philippines and Thailand (shown in Figure 1) was no less dramatic—especially after 1995, when Japanese and European bank lending to emerging Asia escalates.

The bottom right panel of Figure 1 shows the evolution of capital flows to all emerging markets and the progression of crises. The halcyon days of capital flows to emerging markets took place during the first half of the 1990s and held up at least for a short time after Mexican crisis and its contagious effects on Argentina. But the East Asian crisis brings another wave of contagion along the marked decline in capital flows 
in 1997. The Russian crisis of August 1998 delivers another blow from which emerging market flows never fully recover in the 1990s. As shown in the right bottom panel of Figure 1, this crisis is associated with the second major leg of decline in private capital flows to emerging markets. Since Figure 1 is based on annual capital flow data, it significantly blurs the stark differences in capital flows during the pre- and post-Russia crisis. Figure 2, which plots weekly data on emerging market bond issuance before (negative numbers) and after (positive numbers) the Russian default (dashed line) and, for contrast, the Brazilian devaluation on January 1999 (solid line). The vertical line marks the week of the crisis. It is evident that bond issuance collapses following the Russian crisis and remains for over two months following the event; by contrast, the Brazilian devaluation had no discernible impact on issuance, which actually increases following the devaluation.

As Figure 1 highlights, the next three crises--the Brazilian devaluation of January 1999, the Turkish devaluation of February 2001, and the Argentine default at the end of 2001 - take place during the downturn of the cycle and at levels of net capital inflows that were barely above the levels of the 1980s drought. Indeed, the estimates of capital flows to emerging markets in recent years shown in Figure 1, indeed, may actually be overstated because total net flows include foreign direct investment, which held up better than portfolio bond and equity flows.

\section{Surprise Crises and Anticipated Catastrophes}

Fast and furious crises and contagion cases have a high degree of surprise associated with them while their quieter counterparts are more broadly anticipated. This 
distinction appears to be critical when "potentially affected countries" have a common lender. If the common lender is surprised by the shock in the initial crises country, there is no time ahead of the impending crisis to rebalance portfolios and scale back from the affected country. In contrast, if the crisis is anticipated, investors have time to limit the damage by scaling back exposure or hedging their positions.

Evidence that quieter episodes were more anticipated than the fast and furious cases is presented in Table 5. Standard and Poor's credit ratings had remained unchanged during the twelve months prior to of the Mexican and Thai currency crises. In the case of Russia, the credit rating is actually upgraded as late as June 1998 when the broader definition that includes Credit Watch (CW) status is used. The CW list lists the names of credits whose Moody's ratings have a likelihood of changing. These names are actively under review because of developing trends or events which warrant a more extensive examination. Two downgrades eventually take place prior to the crises on August 13, 1998 and again on the $17^{\text {th }}$, the day before the default. By contrast, Argentina has a string (five) of downgrades as it marched toward default, with the first one taking place in October 2000, over a year before the eventual default. Likewise, Brazil and Turkey suffered downgrades well before the eventual currency crisis.

As further evidence that markets anticipated some of the shocks and not others, Figure 3 plots of the domestic-international interest rate differential for the Emerging Market Bond Index (EMBI) and the EMBI+ for two of the contagious episodes (Mexico and Russia, top panels) and for two crises without immediate international repercussions (Argentina and Brazil, bottom panels). ${ }^{7}$ The patterns shown in these four panels are representative of the behavior of spreads ahead of anticipated and unanticipated crises. 
(The vertical axis is measured in basis points, so a measure of 1000 means a gap of 10 percentage points between the domestic borrowing rate and the international benchmark.) If bad things are expected to happen, risk increases and spreads should widen. The overall message is that fast and furious episodes are accompanied by sharp spikes in yield differentials - reflecting the unanticipated nature of the news -- whereas other episodes have tended to be anticipated by financial markets.

The top left panel of Figure 3, which shows the evolution of Mexico's spread in the pre-crisis period is striking. In Mexico, spreads are stable at around 500 basis points in the months and weeks prior to the December 21, 1994 devaluation. Indeed Mexico's spreads remained below 1,000 until the week of January 6, 1995. Russian spreads, illustrated in the top right panel of Figure 3, show remarkable stability until a couple of weeks prior to the announcement and default. In the case of Russia, the devaluation of the ruble appears to have been widely expected by the markets, as evident on the spreads on ruble-denominated debt. One can conjecture that it was either the actual default or the absence of an IMF bailout (following on the heels of historically large bail-out packages for Mexico and Korea) that took markets by surprise.

The data presented in Figure 3 bottom panel illustrates the fact that markets foreshadowed turbulence in the cases of Argentina (2001) and Brazil (1999). The left bottom panel of Figure 3 presents evidence for interest rate spreads for Argentina and shows that the cost of borrowing began to rise steadily and markedly well before its default on December 23, 2001. In effect, since the week of April 22,spreads began to settle above 1,000 and since July 20 the never fell below 1,500. The bottom right panel of Figure 3 shows Brazilian spreads. There is a run-up in spreads well before Brazil floats 
the real on February 1,1999. This chart also reveals that Brazil—more so than Argentina — was quickly and markedly affected by the Russian crisis.

In sum, we have provided suggestive evidence that anticipated crises are preceded by credit ratings downgrades and widening interest spreads before the crisis while for unanticipated crises the downgrades and widening of spreads come during the crisis or after the fact.

\section{Common Creditors}

As noted, international banks played an important role in the transmission of some of the crises of the 1980s and the 1990s. In the 1980s it was U.S. banks lending heavily to Latin America while in the 1990s it was European and Japanese bank lending to Asia, the transition economies and, in the case of Spanish banks, Latin America. In the remainder of this section, we discuss the role that commercial banks and mutual and hedge funds have played in the recent contagion episodes.

International bank lending to the Asian crisis countries grew at a 25 percent annual rate from 1994 to 1997 (or at a pace of about US\$40 billion inflow per year.) At the onset of the crisis, European and Japanese banks' lending to Asia was at its peak at US\$165 and US\$124 billion, respectively, while the exposure of US banks was much more limited. Japanese banks had the highest exposure to Thailand, which also accounted for 26 percent of their total lending to emerging markets (the largest representation of any emerging market country in their portfolio.) Collectively, the Asian crisis countries (excluding the Philippines, which did not borrow much from Japanese banks), accounted for 65 percent of the emerging market loan portfolio of Japanese banks. For European banks, the comparable share was 23 percent. Following the floatation of the Thai baht on 
July 2, 1997, the exposed banks retrenched quickly and cut credit lines to emerging Asia. The bank inflows quickly became outflows of about US $\$ 47$ billion.

As with Asia, lending to transition economies had accelerated in the mid-1990s. In the three years before the Russian crisis, international bank lending to the region grew at 14 percent per annum. German banks were more heavily exposed to Russia, with lending to Russia averaging about 20 percent of all their lending to emerging economies. As with earlier fast and furious contagion episodes, bank flows to the region, which oscillated around US\$28 billion per year in the years before the crisis, turned into a US\$14 billion dollar outflow in the year following the crisis. This retrenchment in lending helps explain why other transition economies were affected by the Russian crisis. However, it fails to explain why Brazil, Hong Kong, and Mexico come under significant pressures at this time. To understand these and other cases, we need to turn our attention to non-bank common creditors.

Equity and bond flows also declined sharply in the aftermath of the fast and furious crises of the 1990s. For example, U.S.-based mutual funds specialized in Latin America withdrew massively from the region following the Mexican crisis in 1994. As discussed in Kaminsky, Lyons, and Schmukler (2002), withdrawals from Latin America oscillated around 40 percent in the immediate aftermath of the crisis. The countries most affected were Argentina, Brazil, and (of course) Mexico, which were the countries to which the mutual funds were most heavily exposed to in Latin America at the time of the crisis. For example, if one examines the Latin American portfolio of mutual funds specialized in emerging markets at around the time of the crisis, Brazil, Mexico, and 
Argentina account for 37, 26, and 14 percent of their portfolio, respectively (i.e., three countries accounted for 77 percent of the Latin American portfolio)!

The Thai crisis in 1997 also triggered equity outflows through mutual funds from Asia. As discussed in Kaminsky, Lyons, and Schmukler (2002), the countries most affected by abnormal withdrawals were Hong Kong, Singapore, and Taiwan, the countries with the most liquid financial markets in the region. As was the case of the Mexican crisis, these were the countries to which mutual funds were heavily exposed. Of the portfolio allocated to Asia, 30 percent was directed to Hong Kong, 7 percent to Singapore, and 13 percent to Taiwan. They estimate that abnormal withdrawals (relative to the mean flow during the whole sample) oscillated at around 10 percent for the three economies.

Similarly, highly leveraged funds seem to have had an important role in the speculative attack against Hong Kong dollar in August of 1998 following the Russian crisis see Corsetti, Pesenti, and Roubini (2001). According to the Financial Stability Forum 2000 Report of the Market Dynamics Study Group of the FSF Working Group on Highly Leveraged Institutions (2000), large macro hedge funds appear to have detected fundamental weaknesses early and started to build large short positions against the Hong Kong dollar. According to available estimates, hedge funds' short positions in the HK\$ market were close to 10 billion U.S. dollars (6 percent of Hong Kong's GDP), but some observers believe that the correct figure was much higher. Several large hedge funds also took very large short positions in the equity markets, and these positions were correlated over time. As reported in the FSF study, among those taking short positions in the equity market were four large hedge funds, whose futures and options positions were equivalent 
to around 40 percent of all outstanding equity futures contracts as of early August prior to the Hong Kong Monetary Authority (HKMA) intervention. Position data suggest a correlation, albeit far from perfect, in the timing of the establishment of the short positions. Two hedge funds substantially increased their positions during the period of the HKMA intervention. At end August, four hedged funds accounted for 50,500 contracts or 49 percent of the total open interest/net delta position; one fund accounted for one third. The group's meetings suggested that some large highly leveraged institutions had large short positions in both the equity and currency markets.

\section{Concluding Reflections}

To date, what has distinguished the contagion episodes that happened from those that could have happened seems to have had little to do with more "judicious" and "discriminating" investors - nor with any improvements to boast of in the state of the international financial architecture. If investors behaved in a more discriminating manner in the recent crises where contagion could have happened but did not, it is because: i) those crises tended to unfold in slow motion and were thus widely anticipated; and ii) the capital flow bubble had been pricked at an earlier stage, when those same investors were more "exuberant" and iii) hence, the "common creditor" we have stressed in our discussion was less leveraged in these episodes. When looking back into history, one is struck by an overwhelming sense of "déjà vu. It certainly seems a mystery why episodes of financial crises and contagion recur, in spite of the major costs associated with crises (this would seem to provide a sufficient motivation for avoiding them.) But based on historical experience, there appears to be little hope that during the good times future 
generations of sovereign borrowers or investors will remember that the four most expensive words in financial history are "this time it's different."

If history is any guide, financial crises will not be eliminated — as Kindleberger (1977) noted, they are hardy perennials. But it should be possible, based on the understanding of what causes contagion and what does not, for countries to take steps to reduce their vulnerability to international contagion.

Contagion appears to be linked to a substantial inflow of capital to a country. Of course, the prospect of financial autarky as a way of avoiding fast and furious contagion is not particularly attractive as a long run solution. In fact, it may not even be feasible when countries have already liberalized the financial sector and the capital account. But before turning to the issue of capital account restrictions, it is critical to remember that in many crises (most of those discussed here and many others), the lead and largest borrower in international capital markets during the boom periods are the sovereign governments themselves. As Reinhart, Rogoff, and Savastano (2003) observe, it is the most debt intolerant countries with a history of serial default that can least afford to borrow that usually borrow the most. Often the outcome is default.

So, as a first important step, the risk of contagion would be reduced if policymakers in countries that are integrated with world capital markets remember that many a surge in capital inflows often ends in a sudden stop — whether owing to homegrown problems or contagion from abroad. As a consequence, prudent policymaking would at a minimum ensure that the government does not overspend and overborrow when international capital markets are all too willing to lend, as most of those episodes end in tears. In contrast, fiscal policy in emerging markets currently tends to be markedly 
procyclical, with countries engaging in expansionary fiscal policy in good times and contractionary fiscal policy in bad times (Talvi and Végh, 2000). Fiscal reforms aimed at designing institutional mechanisms that would discourage such procyclical behavior (particularly on the part of "provinces" or other autonomous entities) appear as an essential ingredient in preventing future crises from building up. Such consistent self discipline, however, on the part of governments has historically proved elusive.

As regards to curbing private borrowing from abroad, the issues are even more complex. The best case for restrictions on international financial inflows would seem to focus on debt contracts with short maturities that are denominated in a foreign currencywhich have been the trigger in many modern contagion episodes. But although such policies may help in tilting the composition of capital flows toward longer maturities, their overall long-term effectiveness is unclear. Curbing capital outflows, once contagion and the ensuing sudden stop has occurred, is even more problematic. Experience has shown that capital flight has been an endemic problem for countries that have tried to turn the clock back and re-introduce tight capital account and financial restrictions amidst economic turmoil. More fundamentally, pervasive capital controls hardly seem likely to be the solution in the medium and long run to the contagion and sudden stop problem.

As to new mechanisms in financial centers that could curb these periodic bouts of lending and "irrational exuberance" and lessen the likelihood of unpleasant future surprises, we remain very skeptical that there are easy or obvious solutions. Access to more information may not lessen surprises when borrowers and lenders have often shown themselves willing to downplay worrisome fundamentals that are in the public 
domain in the late 1990s under the guise of having superior information. The economic historian Max Winkler wrote:

"The over-abundance of funds, together with the difficulty of finding the most profitable employment therefore at home has contributed greatly to the pronounced demand for and the ready absorption of large foreign issues, irrespective of quality... While high yield on a foreign bond does not necessarily indicate inferior quality, great care must be exercised in the selection of foreign bonds, especially today, when anything foreign seems to find a ready market...Promiscuous buying, however, is destined to prove disastrous.”

In 1929 a wave of currency crises swept through Latin America-it was quickly followed by a string of defaults on sovereign external debt obligations. At the time of this writing, with investors searching for high yields quickly snapping up emerging market bonds, Winkler's warning rings as true now as it did then. 


\section{References}

Banerjee Abhijit. 1992. “A Simple Model of Herd Behavior.” Quarterly Journal of Economics. August, CVII:3, pp. 797-817.

Basu, Ritu. 1998. “Contagion Crises: The Investor's Logic.” Mimeograph, University of California, Los Angeles.

Bikhchandani Sushil, David Hirshleifer, and Ivo Welch. 1992. "A Theory of Fads, Fashion, Custom, and Cultural Change as Informational Cascades." Journal of Political Economy. 100:5, pp. 992-1026

Bikhchandani Sushil, David Hirshleifer, and Ivo Welch. 1998. "Learning from the Behavior of Others: Conformity, Fads, and Informational Cascades." Journal of Economic Perspectives. Summer, 2:3, pp. 151-170.

Bordo, Michael and Barry Eichengreen. 1999. "Is Our Current International Economic Environment Unusually Crisis Prone?” International Financial System. Conference Proceedings. (eds.) David Gruen and Luke Gower. Capital Flows and the Reserve Bank of Australia. Sydney.

Bordo, Michael and Antu P. Murshid. 2000. "The International Transmission of Financial Crises before World War II: Was there Contagion.” Mimeograph.

Caballero, Ricardo, and Arvind Krishnamurthy. 2003. "Smoothing Sudden Stops." Journal of Economic Theory, forthcoming.

Calvo, Guillermo. 1998. "Capital Market Contagion and Recession: An Explanation of the Russian Virus.” Mimeograph.

Calvo, Guillermo and Enrique Mendoza. 2000. "Rational Contagion and the Globalization of Securities Markets.” Journal of International Economics. June 51:1, pp. 79-113.

Calvo, Guillermo and Carmen Reinhart. 2000. "When Capital Inflows Come to a Sudden Stop: Consequences and Policy Options" in Reforming the International Monetary and Financial System, P. Kenen and A. Swoboda, eds. Washington DC: International Monetary Fund, pp. 175-201.

Caramazza, Franceso, Luca Ricci, and Ranil Salgado. 2000. "Trade and Financial Contagion in Currency Crises.” IMF Working Paper WP/00/55.

Corsetti, Giancarlo, Paolo Pesenti, and Nouriel Roubini. 2001 "The Role of Large Players in Currency Crises.” NBER Working Paper 8303, May.

Dawson, Frank G. 1990. The First Latin American Debt Crisis. New Haven and London: Yale University Press. 
Diaz-Alejandro, Carlos. 1984. "Latin American Debt: I Don't Think We Are in Kansas Anymore." Brookings Papers on Economic Activity. 2, pp. 335-403.

Doukas, John. 1989. “Contagion Effect on Sovereign Interest Rate Spreads.”, Economic Letters. $29,237-241$.

Eichengreen, Barry, Andrew Rose, and Charles Wyplosz. 1996. "Contagious Currency Crises: First Tests.” Scandinavian Journal of Economics. 98, pp. 463-484.

Frankel, Jeffrey and Sergio Schmukler. 1998. "Crises, Contagion and Country Funds: Effects on East Asia and Latin America," in Managing Capital Flows and Exchange Rates: Perspectives from the Pacific Basin. Reuven Glick, ed. New York: Cambridge University Press, pp. 232-266

Gerlach, S. and Frank Smets. 1996. “Contagious Speculative Attacks.” CEPR Discussion Paper No. 1055.

Glick, Reuven and Andrew Rose. 1999. "Contagion and Trade: Why Are Currency Crises Regional.” Journal of International Money and Finance. August, 18:4, pp. 603-617.

Goldstein, Morris. 1998. The Asian Financial Crisis. Washington, DC: Institute for International Economics.

International Monetary Fund, Capital Markets Report. Various issues.

International Monetary Fund, World Economic Outlook. Various issues.

Kaminsky, Graciela and Carmen Reinhart. 2000. "On Crises, Contagion, and Confusion." Journal of International Economics. June, 51:1, pp. 145-168.

Kaminsky, Graciela and Sergio Schmukler. 1999. "What Triggers Market Jitters? A Chronicle of the Asian Crisis." Journal of International Money and Finance. August, 18:4, pp. 537-560.

Kaminsky, Graciela, Richard Lyons, and Sergio Schmukler. 2000. "Managers, Investors, and Crises: Mutual Fund Strategies in Emerging Markets.” NBER Working Paper No. 7855.

Kaminsky, Graciela, Richard Lyons, and Sergio Schmukler 2002 "Liquidity, Fragility, and Risk: The Behavior of Mutual Funds During Crises." Mimeograph.

Kindleberger, Charles P., 1977, Manias, Panics, and Crashes. John Wiley \& Sons, $4^{\text {th }}$ edition.

Kodres, Laura, and Matthew Pritsker. 2002. “A Rational Expectations Model of Financial Contagion.” Journal of Finance. April, LVII:2, pp. 769-800. 
Lahiri, Amartya, and Carlos A. Végh. 2003. "Delaying the Inevitable: Optimal Interest Rate Defense and BOP Crises," Journal of Political Economy, forthcoming.

Mody, Ashok and Mark Taylor. 2002. “Common Vulnerabilities.” Mimeograph.

Neal, Larry and Marc Weidenmeir. 2002. "Crises in the Global Economy from Tulips to Today: Contagion and Consequences.” National Bureau of Economic Research Working Paper 9147. September.

Nurkse, Ragnar. 1944. International Currency Experience: Lessons of the Interwar Period, Geneva: League of Nations.

Reinhart, Carmen M., Kenneth S. Rogoff, and Miguel A. Savastano. 2003. "Debt Intolerance." Brookings Papers on Economic Activity, Spring 1, pp. 1-62..

Shleifer Andrei and Robert W. Vishny: The Limits of Arbitrage, Journal of Finance, vol. LII, no 1, March 1997, pp. 35-55

Talvi, Ernesto and Carlos A. Végh, 2000. "Tax Base Variability and Procyclical Fiscal Policy." NBER Working Paper No. 7499.

Van Rijckeghem, Caroline and Beatrice Weder. 2000. "Financial contagion: Spillovers through Banking Centers." Mimeograph.

Winkler, Max. 1933. Foreign Bonds: An Autopsy. Philadelphia: Roland Swain Company. 


\section{Table 1}

\section{Financial Crises with Immediate International Repercussions: 1980-2000}

\begin{tabular}{|c|c|c|}
\hline $\begin{array}{l}\text { Origin of the shock, } \\
\text { country and date }\end{array}$ & $\begin{array}{c}\text { Nature of common external } \\
\text { shock, if any }\end{array}$ & Contagion mechanisms \\
\hline $\begin{array}{l}\text { On August } 1982 \\
\text { Mexico defaults on its } \\
\text { external bank debt. By } \\
\text { December, the peso } \\
\text { had depreciated by } 100 \\
\text { percent. }\end{array}$ & $\begin{array}{l}\text { Between } 1980 \text { and } 1985 \text {, } \\
\text { commodity prices fell by } \\
\text { about } 31 \text { percent. US short } \\
\text { term real interest rates rise } \\
\text { to about } 10 \text { percent, the } \\
\text { highest levels since the } \\
\text { depression. }\end{array}$ & $\begin{array}{l}\text { U.S. banks, heavily } \\
\text { exposed to Mexico, } \\
\text { retrenched from } \\
\text { emerging markets }\end{array}$ \\
\hline $\begin{array}{l}\text { On September } 8,1992 \\
\text { the Finnish markka is } \\
\text { floated and the ERM } \\
\text { crisis unfolds. }\end{array}$ & $\begin{array}{l}\text { High interest rates in } \\
\text { Germany. Rejection by } \\
\text { Danish voters of the } \\
\text { Maastricht treaty. }\end{array}$ & Hedge funds. \\
\hline $\begin{array}{l}\text { On December } 20,1994 \\
\text { Mexico announced a } \\
15 \text { percent devaluation } \\
\text { of the peso. It sparked } \\
\text { a confidence crisis and } \\
\text { by March } 1995 \text { the } \\
\text { peso's value had } \\
\text { declined by about } 100\end{array}$ & $\begin{array}{l}\text { From January } 1994 \text { to } \\
\text { December, the Federal } \\
\text { Reserve raised the federal } \\
\text { funds rate by about } 2 \frac{1}{2} \\
\text { percentage points. }\end{array}$ & $\begin{array}{l}\text { Mutual funds sell off } \\
\text { other Latin American } \\
\text { countries, notably } \\
\text { Argentina and Brazil. } \\
\text { Massive bank runs and } \\
\text { capital flight in } \\
\text { Argentina. }\end{array}$ \\
\hline
\end{tabular}

percent.

On July 2 1997, Thailand announces that the baht will be allowed to float. By January 1998 the baht had depreciated by about 113 percent.

On August 18, 1998, Russia defaults on its domestic bond debt. Between July 1998 and January 1999, the ruble depreciated by 262 percent. On September 2, 1998, it became public knowledge that LTCM had gone bankrupt.
Countries affected

With the exception of Chile, Colombia and Costa Rica all countries in Latin America defaulted.

All the countries in the European Monetary System except Germany.

Argentina suffered the most, losing about 20 percent of deposits in early 1995. Brazil was next, while losses in other countries in the region limited to declines in equity prices.

Japanese banks, exposed to Thailand, retrenched from emerging Asia. As Korea is affected, European banks also withdraw.

Indonesia, Korea, Malaysia, and the Philippines were hit hardest. Financial markets in Singapore and Hong Kong also experienced some turbulence.

\footnotetext{
Margin calls and leveraged hedge funds fueled the sell off in other emerging and high yield markets. It is difficult to distinguish contagion from Russia and fear of
} Apart from several of the former Soviet republics, Hong Kong, Brazil, and Mexico were hit hardest. But most emerging and developed markets were affected.

Sources: International Monetary Fund, International Financial Statistics, dates of the default or restructurings are taken from Reinhart, Rogoff, and Savastano (2003). 
Table 2

\section{Selected Financial Crises without Immediate International Repercussions: 1999-2001}

\begin{tabular}{|c|c|}
\hline $\begin{array}{l}\text { Origin of the shock: } \\
\text { country and date }\end{array}$ & $\begin{array}{l}\text { Background on the run-up } \\
\text { to the shock }\end{array}$ \\
\hline $\begin{array}{l}\text { On January } 13,1999 \\
\text { Brazil devalues the } \\
\text { real and eventually } \\
\text { floats on February } 1 \text {. } \\
\text { Between early January } \\
\text { and end-February the } \\
\text { real depreciates by } 70 \\
\text { percent. }\end{array}$ & $\begin{array}{l}\text { The crawling peg exchange } \\
\text { rate policy (the Real Plan) } \\
\text { that was adopted in July } \\
1994 \text { to stabilize } \\
\text { inflation is abandoned. }\end{array}$ \\
\hline $\begin{array}{l}\text { Turkey, } \\
\text { February 22, } 2001 \\
\text { Devaluation and } \\
\text { floatation of the lira }\end{array}$ & $\begin{array}{l}\text { Facing substantial external } \\
\text { financing needs, in late } \\
\text { November } 2000 \text {, rumors of } \\
\text { the withdrawal of external } \\
\text { credit lines to Turkish banks } \\
\text { triggered a foreign exchange } \\
\text { outflows and overnight rates } \\
\text { soared to close to } 2,000 \\
\text { percent. }\end{array}$ \\
\hline
\end{tabular}

On December 23, 2001, the president of Argentina announces intentions to default.

Following several waves of capital flight, on December $1^{\text {st }}$ capital controls are introduced.
Spillover mechanisms

Countries affected
There is an increase in volatility in some of larger equity markets and Argentina spreads widened. Equity markets in Argentina and Chile rallied. These effects lasted only a few days.

Significant and protracted effect on Argentina, as Brazil is Argentina's largest trading partner.

There has been some conjecture that the Turkish crisis may have exacerbated the withdrawal of investors from Argentina but given the weakness in Argentina's fundamentals at the time, it is difficult to suggest developments owed to contagion.

Bank deposits fall by more than 30 percent in Uruguay, as Argentines withdraw deposits from Uruguayan banks. Significant effects on economic (trade and tourism) activity in Uruguay.
Uruguay and, to a much lesser extent, Brazil 
Table 3

\section{Propagation Mechanisms in Episodes of Contagion}

\begin{tabular}{|c|c|c|c|}
\hline Episode & Trade & $\begin{array}{c}\text { Common characteristic across } \\
\text { affected countries }\end{array}$ & Common creditor \\
\hline $\begin{array}{l}\text { Mexico, } \\
\text { August } 1982\end{array}$ & $\begin{array}{l}\text { As the entire region was } \\
\text { affected, trade links are } \\
\text { significant, even though } \\
\text { there are low levels of } \\
\text { bilateral trade among most of } \\
\text { the affected countries. }\end{array}$ & $\begin{array}{l}\text { Large fiscal deficits, weak } \\
\text { banking sectors, dependence on } \\
\text { commodity prices and heavy } \\
\text { external borrowing. }\end{array}$ & U.S. commercial banks. \\
\hline $\begin{array}{l}\text { Finland, } \\
\text { September 8, } \\
\text { 1992--ERM } \\
\text { crisis }\end{array}$ & $\begin{array}{l}\text { While bilateral exports to } \\
\text { Finland from the affected } \\
\text { countries are small, there are } \\
\text { substantial trade links among } \\
\text { all the affected countries. }\end{array}$ & $\begin{array}{l}\text { Large capital inflows, common } \\
\text { exchange rate policy as part of } \\
\text { the EMS. }\end{array}$ & Hedge funds. \\
\hline $\begin{array}{l}\text { Mexico, } \\
\text { December 21, } \\
1994\end{array}$ & $\begin{array}{l}\text { No significant trade links. } \\
\text { Bilateral trade with } \\
\text { Argentina and Brazil was } \\
\text { minimal. Only } 2 \text { percent of } \\
\text { Argentina's and Brazil's } \\
\text { exports were destined to } \\
\text { Mexico. Little scope for third } \\
\text { party trade story. Mexico's } \\
\text { exports to the United States } \\
\text { were very different from } \\
\text { Argentine and Brazilian } \\
\text { exports. }\end{array}$ & $\begin{array}{l}\text { Exchange rate based inflation } \\
\text { stabilization plans. Significant } \\
\text { real appreciation of the exchange } \\
\text { rate and concerns about } \\
\text { overvaluation. Large capital } \\
\text { inflows in the run-up to the } \\
\text { crisis. }\end{array}$ & $\begin{array}{l}\text { Primarily US } \\
\text { bondholders, including } \\
\text { mutual funds. }\end{array}$ \\
\hline $\begin{array}{l}\text { Thailand, } \\
\text { July } 21997\end{array}$ & $\begin{array}{l}\text { Bilateral trade with other } \\
\text { affected countries was very } \\
\text { limited. Malaysia exported } \\
\text { similar products to some of } \\
\text { the same third markets. }\end{array}$ & $\begin{array}{l}\text { Heavily managed exchange rates } \\
\text { and large increase in the stock of } \\
\text { short-term foreign currency debt. }\end{array}$ & $\begin{array}{l}\text { European and Japanese } \\
\text { commercial banks } \\
\text { lending to Thailand, } \\
\text { Korea, Indonesia, and } \\
\text { Malaysia. Mutual } \\
\text { Funds sell off Hong } \\
\text { Kong and Singapore. }\end{array}$ \\
\hline $\begin{array}{l}\text { Russia/LTCM, } \\
\text { August 18, } \\
1998\end{array}$ & $\begin{array}{l}\text { Virtually no trade with the } \\
\text { most affected countries } \\
\text { (bilateral or third party.) } \\
\text { Exports from, Brazil, Mexico } \\
\text { and Hong Kong to Russia } \\
\text { accounted for } 1 \text { percent or } \\
\text { less of total exports for these } \\
\text { countries. }\end{array}$ & $\begin{array}{l}\text { The most liquid emerging } \\
\text { markets, Brazil, Hong Kong and } \\
\text { Mexico were most affected. } \\
\text { These three countries accounted } \\
\text { for the largest shares of mutual } \\
\text { fund holdings. }\end{array}$ & $\begin{array}{l}\text { Mutual funds and hedge } \\
\text { Funds }\end{array}$ \\
\hline
\end{tabular}




\section{Table 4}

\section{Capital Flows and Capital Flight on the Eve of Crises}

\begin{tabular}{|c|c|c|}
\hline Episode & $\begin{array}{c}\text { Capital flow background in crisis } \\
\text { country }\end{array}$ & $\begin{array}{l}\text { Capital flow background in other } \\
\text { relevant countries }{ }^{1}\end{array}$ \\
\hline \multicolumn{3}{|c|}{ Fast and furious episodes } \\
\hline $\begin{array}{c}\text { Exchange Rate Mechanism } \\
\text { Crisis: }\end{array}$ & $\begin{array}{l}\text { Net capital flows to Finland had } \\
\text { risen from less than } \$ 2 \text { billion in }\end{array}$ & $\begin{array}{l}\text { In } 1989 \text { private net capital flows } \\
\text { to the European Union (EU) were }\end{array}$ \\
\hline Finland September 8, 1992 & $\begin{array}{l}1988 \text { to } \$ 9 \text { billion at their peak in } \\
1990 \text {. Portfolio flows, which } \\
\text { were about } \$ 3 \text { billion in } 1988 \text {, } \\
\text { however, hit their peak prior to } \\
\text { the crisis in } 1992 \text { at } \$ 8 \text { billion. }\end{array}$ & $\begin{array}{l}\text { about } \$ 11 \text { billion (US dollars) in } \\
1992, \text { on the eve of the crisis } \\
\text { these had risen to } \$ 174 \text { billion. }\end{array}$ \\
\hline Tequila Crisis: & In 1990 private net capital flows & Net flows to the other major Latin \\
\hline Mexico, December 21, 1994 & $\begin{array}{l}\text { were less than } \$ 10 \text { billion (US } \\
\text { dollars) by } 1993 \text { flows had risen } \\
\text { to } \$ 35 \text { billion. Estimates of } \\
\text { capital flight showed a } \\
\text { repatriation through } 1994 \text {. }\end{array}$ & $\begin{array}{l}\text { American countries had also risen } \\
\text { sharply, for Western Hemisphere } \\
\text { as a whole it went from net } \\
\text { outflows in } 1989 \text { to inflows of } \\
\$ 47 \text { billion in } 1994 \text {. }\end{array}$ \\
\hline $\begin{array}{c}\text { Asian Crisis: } \\
\text { Thailand, July 2, } 1997\end{array}$ & $\begin{array}{l}\text { From } 1993 \text { to } 1996 \text { net capital } \\
\text { flows to Thailand doubled to } \\
\text { about } \$ 20 \text { billion (US dollars). In } \\
1997 \text { capital outflows amounted } \\
\text { about } \$ 14 \text { billion. }\end{array}$ & $\begin{array}{l}\text { Flows to emerging Asia had risen } \\
\text { from less than } \$ 10 \text { billion (US } \\
\text { dollars) to almost } \$ 80 \text { billion in } \\
1996 .\end{array}$ \\
\hline Russian Crisis: August 18, 1998 & $\begin{array}{l}\text { While total flows into Russia } \\
\text { peaked in } 1996 \text {, foreign direct } \\
\text { investment peaked in } 1998 \text {, rising } \\
\text { from about } \$ 0.1 \text { billion in } 1992 \text { to } \\
\$ 2.2 \text { billion in } 1998 \text {. }\end{array}$ & $\begin{array}{l}\text { Excluding Asia, which witnessed } \\
\text { a sharp capital flow reversal in } \\
\text { 1997, capital flows to other } \\
\text { emerging markets remained } \\
\text { buoyant through } 1997 \text { and early } \\
1998 \text {, having risen from about } \$ 9 \\
\text { billion in } 1990 \text { to } \$ 125 \text { billion in } \\
1997 .\end{array}$ \\
\hline \multicolumn{3}{|c|}{ Cases without immediate international consequences } \\
\hline $\begin{array}{c}\text { Brazil Devalues and Floats: } \\
\text { February 1, } 1999\end{array}$ & $\begin{array}{l}\text { Repatriation of capital flight } \\
\text { amounted to about } 3 \text { percent of } \\
\text { GDP in } 1996 \text {. By early } 1998 \text { it } \\
\text { had reversed into capital flight. } \\
\text { Yet net capital flows did not } \\
\text { change much between } 1997 \text { and } \\
\text { 1999, currency crisis } \\
\text { notwithstanding. }\end{array}$ & $\begin{array}{l}\text { At about } \$ 54 \text { billion (US dollars) } \\
\text { in } 1999 \text {,capital flows to Western } \\
\text { Hemisphere well below their } \\
\text { peak ( } \$ 85 \text { billion) in } 1997 .\end{array}$ \\
\hline $\begin{array}{l}\text { Turkey floats the lira } \\
\text { February } 22,2001\end{array}$ & $\begin{array}{l}\text { While repatriation amounted to } \\
\text { about } 2 \text { percent of GDP during } \\
\text { 1997-1999, capital flight began in } \\
\text { earnest in } 2000 .\end{array}$ & $\begin{array}{l}\text { Following the successive crises in } \\
\text { Asia (1997) and Russia (1998) } \\
\text { private capital flows to emerging } \\
\text { markets had all but dried up by } \\
2001 \text {. At a meager } \$ 20 \text { billion in } \\
2001 \text {, flows were } \$ 200 \text { billion off } \\
\text { their peak in } 1996 \text {. }\end{array}$ \\
\hline $\begin{array}{l}\text { Argentina Defaults: } \\
\text { December 23, } 2001\end{array}$ & $\begin{array}{l}\text { Until 1998, capital abroad was } \\
\text { being repatriated. By } 1999 \text {, } \\
\text { however, capital flight amounted } \\
\text { to } 5 \text { percent of GDP. After } \\
\text { several waves of bank runs, } \\
\text { capital flight was estimated at } 6 \\
\text { percent of GDP in } 2001 \text {. }\end{array}$ & (see Turkey commentary) \\
\hline
\end{tabular}


Table 5

\section{Expected and Unexpected Crises: Standard and Poor's Sovereign Credit Ratings Before and After Crises}

\begin{tabular}{ccc}
\hline \hline Crisis Date & Change in rating & \\
& (including Credit Watch) & Change in rating \\
& 12 months prior to the & after the crisis \\
crisis & \\
\hline
\end{tabular}

Fast and Furious Contagion Episodes

\begin{tabular}{|c|c|c|c|}
\hline Mexico & December 21, 1994 & None & $\begin{array}{c}\text { Downgraded two } \\
\text { days after the crisis } \\
\text { December } 23,1994\end{array}$ \\
\hline Thailand & July 2, 1997 & None & $\begin{array}{c}\text { Downgraded in } \\
\text { August }\end{array}$ \\
\hline Russia & August 18, 1998 & $\begin{array}{c}1 \text { upgrade and } \\
2 \text { downgrades (on the } \\
\text { week of the crisis) }\end{array}$ & 1 further downgrade \\
\hline
\end{tabular}

\section{Crises with Limited External Consequences}

$\begin{array}{cccc}\text { Brazil } & \text { February 1, } 1999 & 2 \text { downgrades } & \text { No immediate change } \\ \text { Turkey } & \text { February 22, 2001 } & \begin{array}{c}\text { 1 upgrade and two } \\ \text { downgrades }\end{array} & \begin{array}{c}\text { I further downgrade } \\ \text { the day after the } \\ \text { crisis }\end{array}\end{array}$

$\begin{array}{cc}\text { Argentina } & \text { December 23, 2001 } \\ & \text { October } 2000 \text { and July } \\ 2001\end{array}$

Source: Standard and Poor's, Sovereign Rating History Since 1975.

${ }^{1}$ The international financial turmoil that followed Russia's default was compounded in a significant manner by another negative surprise announcement: on September 2, 1998 it became public knowledge that Long Term Capital Management (LTCM), owing to its large exposure to Russia and other high-yield assets, had gone bankrupt.

${ }^{2}$ As Brazil is Argentina's largest trading partner, the sharp depreciation of the real (about 70 percent between January and end February) left the Argentine peso overvalued. 
Similarly, through its extensive financial and trade links, Uruguay's economy (as it has through history) would be whiplashed by the Argentine crisis.

${ }^{3}$ Of course, there are historical examples of fast and furious contagion before the last few decades. Commonly cited examples of contagion include the first Latin American debt crisis -- which began with Peru's default in April 1826 -- and the international financial crisis of 1873. Going back even further in time, Neal and Weidenmeir (2002) also discuss the "contagion" dimension of the Tulip Mania of the 1630s and the Mississippi and South Sea Bubbles of 1719-20. Two leading examples of financial crises that did not lead to contagion include the well-documented Argentina-Baring crisis of 1890 , and the United States financial crisis of 1907. For detailed accounts of historical episodes of financial crises, see Bordo and Eichengreen (1999), Bordo and Murshid (2000), Kindleberger (2000), and Neal and Weidenmier (2002.)

${ }^{4}$ See Calvo and Reinhart (2000) for an empirical analysis of sudden stop episodes and Caballero and Krishnamurthy. (2003) for a model that traces out the economic consequences of sudden stops.

${ }^{5}$ See Bikhchandani, Hirshleifer, and Welch (1998) for a thoughtful discussion of this literature.

${ }^{6}$ For a detailed discussion of the evolution of these contagion episodes, the interested reader is referred to IMF World Economic Outlook (January 1993) for the ERM crisis, IMF International Capital Markets (August 1995) for the more recent Mexican crisis, Nouriel Roubini's home page http://pages.stern.nyu.edu/ nroubini/ for an excellent chronology of the Asian crisis, and IMF World Economic Outlook and International 
Capital Markets Interim Assessment (December 1998) for Russia’s default and LTCM crisis. Diaz Alejandro (1984) provides a compelling discussion of the debt crisis of the early 1980 s.

${ }^{7}$ The Emerging Market Bond Index Plus (EMBI+) tracks total returns for traded external debt instruments in the emerging markets. While the EMBI covers only Brady bonds, the EMBI+ expands upon the EMBI, covering three additional markets: (1) Eurobonds, (2) U.S. dollar local markets, and (3) loans. The country coverage of the EMBI+ varies over time, currently including 19 members Current members are: Argentina, Brazil, Bulgaria, Colombia, Ecuador, Egypt, Mexico, Malaysia, Morocco, Nigeria, Panama, Peru, Philippines, Poland, Russia, Turkey, Ukraine, Venezuela, and South Africa. The selection of countries and instruments follow four eligibility criteria imposed by JP Morgan Chase: (1) a minimum balance in outstanding, (2) rating, (3) remaining maturity, and (4) ability for international settlement. In order to construct the index of a specific country, a daily total return of each instrument is first computed, and then aggregated by marketcapitalization-weight. 
Figure 1. Net Private Capital Flows, 1985 - 2003

(Billions of U.S. dollars)

\section{European Union}
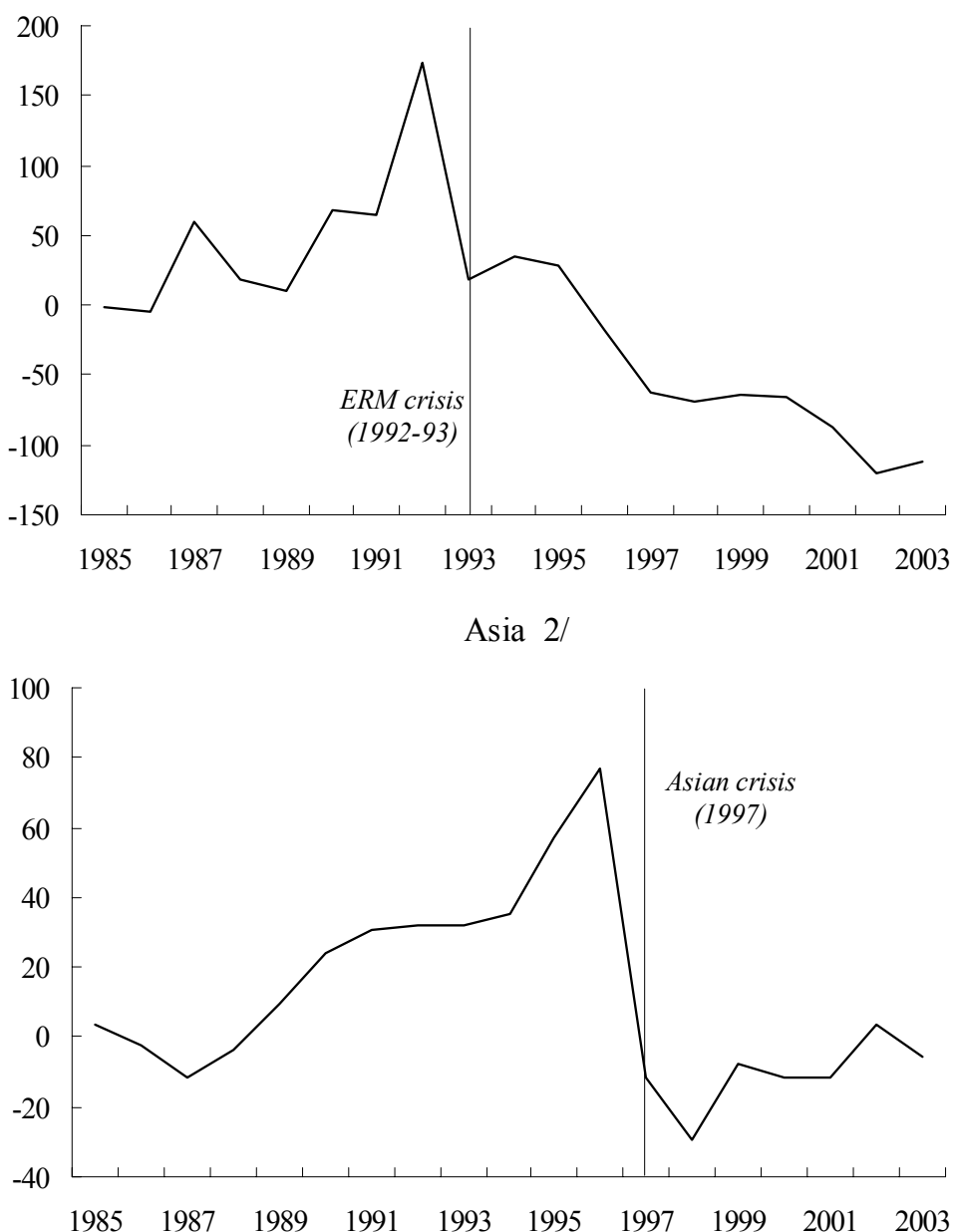

/ Includes Argentina and Mexico.

2/ Includes Indonesia, Malaysia, Philippines, South Korea, and Thailand

Source: IMF, World Economic Outlook.
Western Hemisphere 1/
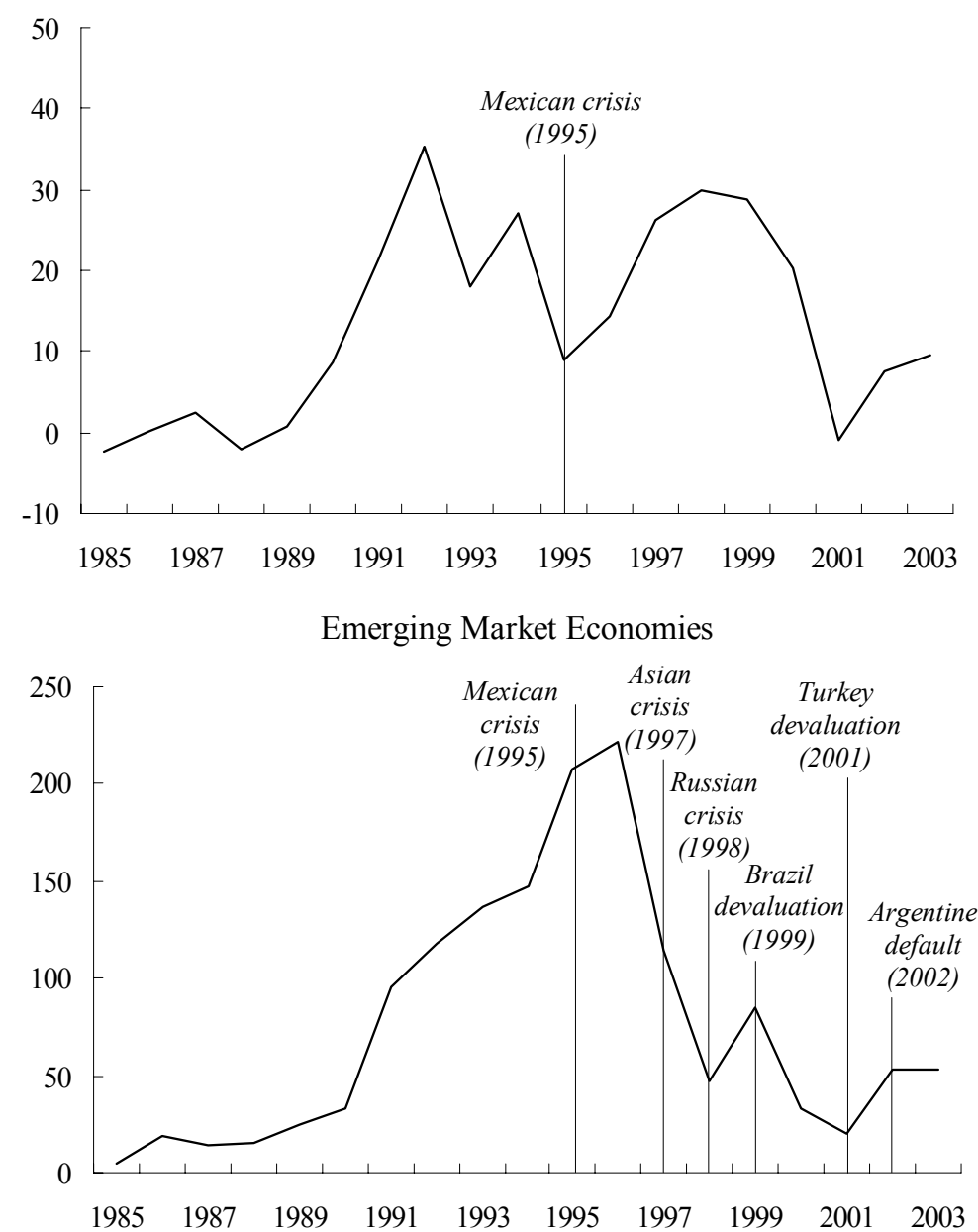

Note: If the crisis occurred in the second half of the year, the vertical line is inserted in the following year. 
Figure 2. Emerging Market: Bond Market Issuance Around Crises 1/ (In billions of U.S. dollars; weekly data, centered three-week moving average)

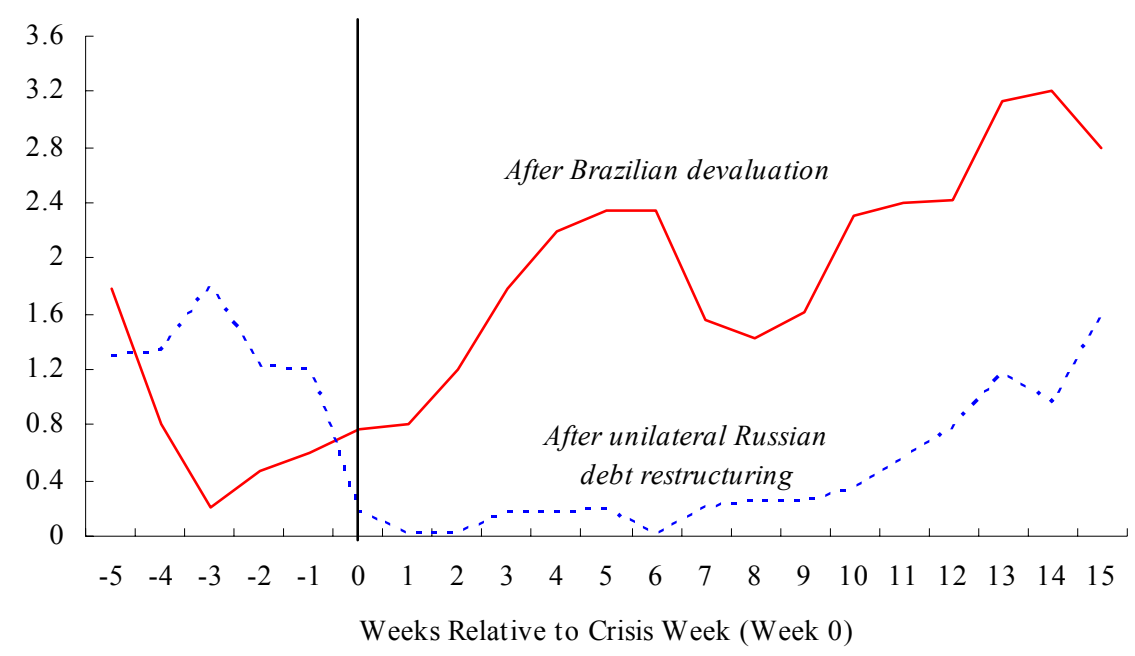

1/ Data prior to Russian default exclude the July 1998 Russian debt exchange.

Source: IMF staff calculations based on data from Capital Data. 
Figure 3. Emerging Market Bond Yield Spreads, $1992-2002$ 1/
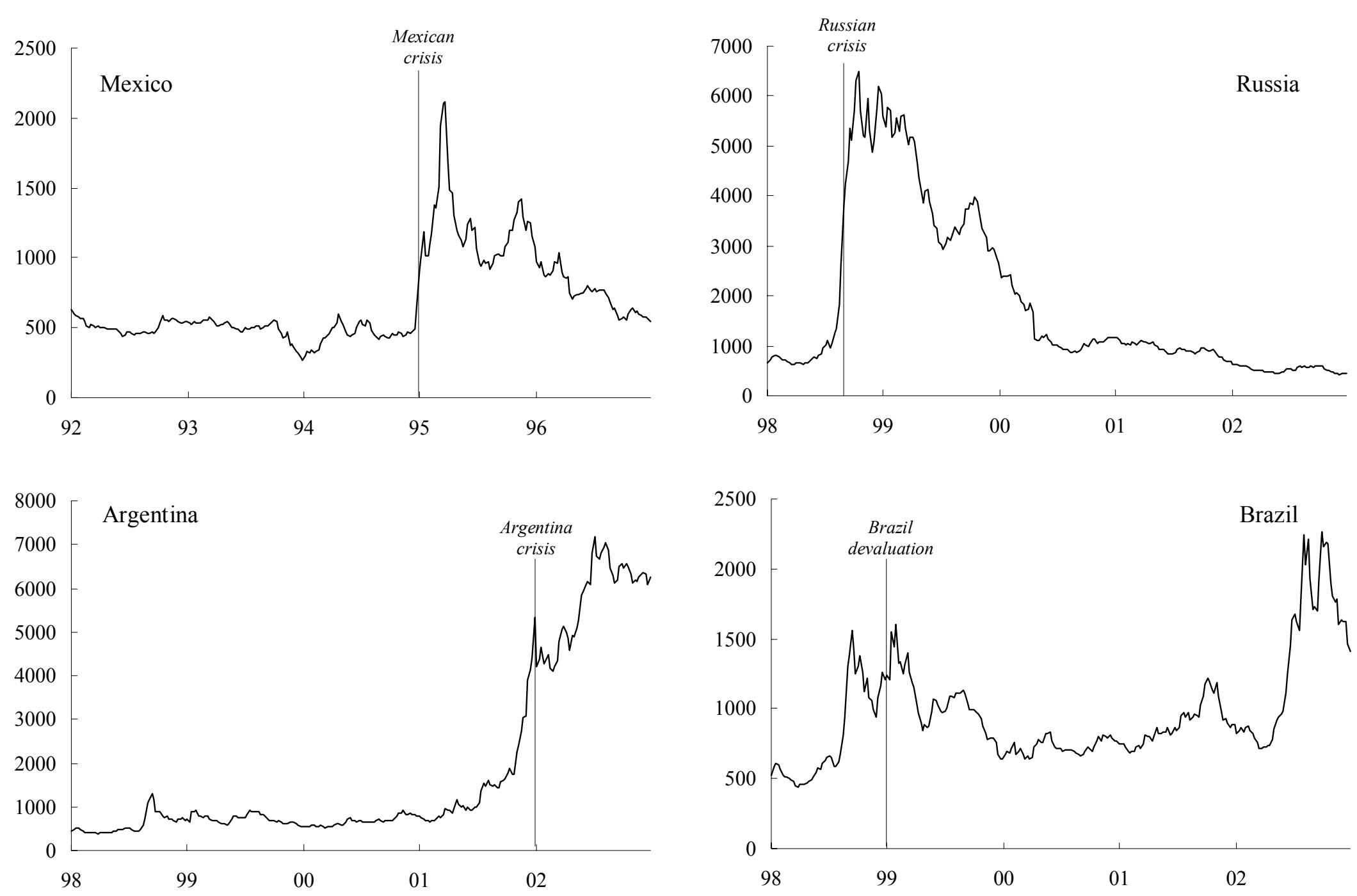

1/ Emerging market bond index plus (EMBI+) spreads are plotted. Source: JP Morgan Chase. 